\title{
Bacterial Canker of Sweet Cherry in Oregon-Infection of Horticultural and Natural Wounds, and Resistance of Cultivar and Rootstock Combinations
}

\author{
Robert A. Spotts and Kelly M. Wallis, Mid-Columbia Agricultural Research and Extension Center, Oregon State \\ University, Hood River 97031; and Maryna Serdani, Department of Botany and Plant Pathology and Anita N. \\ Azarenko, Department of Horticulture, Oregon State University, Corvallis 97331
}

\begin{abstract}
Spotts, R. A., Wallis, K. M., Serdani, M., and Azarenko, A. N. 2010. Bacterial canker of sweet cherry in Oregon-Infection of horticultural and natural wounds, and resistance of cultivar and rootstock combinations. Plant Dis. 94:345-350.

This study was done to (i) compare seven types of natural or horticultural injuries and wounds for incidence, severity, and mortality of infection of sweet cherry (Prunus avium) by Pseudomonas syringae pv. syringae; (ii) determine the relative resistance to bacterial canker of 14 cultivarrootstock combinations; (iii) determine if $P$. syringae pv. syringae is transmitted by contaminated pruning tools; and (iv) determine if summer and winter pruning cuts become resistant to infection. Infection occurred at all of the seven types of injury and wound sites on both cvs. Sunset Bing and Golden Heart. Infection of inoculated wounds made in spring and summer (heading cuts when trees were planted, scoring cuts, and summer pruning) resulted in the greatest canker incidence and severity. Inoculation of heading cuts resulted in the highest tree mortality $(86 \%)$. 'Bing' and 'Sweetheart' were the most susceptible cultivars while 'Regina' and 'Rainier' appeared to be more resistant. Bing trees had the highest mortality of any cultivar with $70 \%$ dead at the end of the 3-year study. Canker severity of the three rootstocks varied considerably but mortality was greatest for trees on Gisela $6(77 \%)$. Bacterial canker was not transmitted in summer or winter by cutting through active cankers, then immediately using the same pruning tool to make heading cuts on healthy trees. Heading cuts became resistant to infection after about 1 week in summer and 3 weeks in winter. Results are discussed as part of an integrated management program for bacterial canker of sweet cherry.
\end{abstract}

Bacterial canker, caused by Pseudomonas syringae pv. syringae van Hall, is a serious disease of sweet cherry (Prunus avium L.) trees worldwide (19). Where conditions have been favorable for disease development, tree losses of $75 \%$ have been observed in young orchards, and under normal conditions losses between 10 and $20 \%$ are not uncommon $(6,27)$. Pseudomonas syringae pv. syringae has been found in healthy-appearing wood and buds of sweet cherry $(8,29)$. Most bud infections are initiated at the bases of the outside bud scales between November and February (7). Infection occurs mainly in young trees in tissue damaged by frost, pruning cuts, or insects, or at leaf scars $(6,14,29)$. Tree mortality is generally greatest in the first 2 years after planting $(12,27)$, and trees are seldom killed after 8 years (6).

Corresponding author: R. A. Spotts

E-mail: robert.spotts@oregonstate.edu

Use of trade names in this article does not imply endorsement by Oregon State University of the products named or criticism of similar products not mentioned.

Accepted for publication 24 November 2009.

doi:10.1094/PDIS-94-3-0345

(C) 2010 The American Phytopathological Society
Several evaluations of rootstocks and cultivars for resistance to $P$. syringae pv. syringae have been conducted. 'Corum' sweet cherry trees had a much lower tree loss than 'Napoleon' trees under Western Oregon conditions. Corum trees were more tolerant of bacterial canker than any of the commercial cultivars, including 'Bing' and 'Lambert', but less tolerant than Mazzard (Prunus avium) and Mahaleb (P. mahaleb) rootstock seedlings or the clonal rootstock selection of $P$. avium known as F12/1 (9). A range of resistance to bacterial canker was reported among 79 wild cherry $(P$. avium) clones in laboratory and field trials (22). Cankers on trees on the semidwarfing rootstock Colt were smaller than on those growing on F12/1 rootstock for both Napoleon and JI 1039 (15). Garrett also confirmed the high susceptibility of Napoleon and the high resistance of JI 14039. More recently, sweet cherry cultivars on Gisela rootstocks have demonstrated an increased susceptibility to bacterial canker in field observations (31), but Gisela clones 4, 6, 7, 8 , and 12 , as well as Mazzard $\times$ Mahaleb $(\mathrm{M} \times \mathrm{M})$ genotypes and $\mathrm{Pi}-\mathrm{Ku} 4$ genotypes $11,17,20$, and 22 , were potentially resistant based on an in vitro excised leaf bioassay and an in vivo twig bioassay $(20,21)$. Weiroot genotypes, tested only in the in vitro bioassay, showed a large necrotic response to Pseudomonas syringae pv. syringae. In Canadian field trials, the On- tario cvs. Viva, Venus, Vic, Vega, and Victor were considered moderately resistant to $P$. syringae pv. syringae compared with Bing and 'Hedelfingen' (1) but did not express the levels of resistance found by Grubb (18) in cultivars such as Roundel, Emperor Francis, or Lambert. Bedford et al. (3), using a detached leaf bioassay, considered 'Merpet' and 'Merchant' as resistant genotypes and Bing, 'Lapins', and 'Sweetheart' as susceptible to bacterial canker. Resistance of many newer rootstocks and cultivars is unknown.

The present study tested the central hypotheses that injury and wound types, as well as rootstocks and cultivars of sweet cherry, vary in susceptibility to infection by $P$. syringae pv. syringae. The objectives of this study were to (i) compare the $P$. syringae pv. syringae infection severity of seven types of natural injuries and wounds, including leaf scars, early winter injury, low-temperature midwinter injury, heading cuts, scoring cuts, summer pruning, and dormant pruning; (ii) determine the relative resistance to bacterial canker of 14 sweet cherry cultivar-rootstock combinations; (iii) determine if $P$. syringae pv. syringae is transmitted with pruning tools; and (iv) determine if summer and winter pruning cuts become resistant to infection.

\section{MATERIALS AND METHODS}

Trees for injury-wound site and cultivar-rootstock studies. Two orchards of sweet cherry trees were planted at Oregon State University Mid-Columbia Agricultural Research and Extension Center, Hood River in 2006 and one orchard in 2007. Cv. Golden Heart on Mazzard rootstock was planted on 30 May 2006. Within-row and between-row tree spacings were 1.5 and $5.5 \mathrm{~m}$, respectively. $\mathrm{Cv}$. Sunset Bing on Gisela 6 rootstock was planted on 9 June 2006. Within-row and between-row tree spacings were 2.4 and $4.6 \mathrm{~m}$, respectively. The third block, consisting of 14 cultivarrootstock combinations with 20 replicate trees for most combinations, was planted 24 April 2007. Within-row and betweenrow tree spacings were 1.2 and $4.6 \mathrm{~m}$, respectively. Trees were grown in commercial nurseries for about 2 years before planting. All trees received standard fertilizer, herbicide, and irrigation programs but did not receive any bactericide, fungicide, or insecticide treatments. 
Inoculum for injury-wound site study with Golden Heart and Sunset Bing. $P$. syringae pv. syringae isolate KM406 was obtained from an infected sweet cherry cv. Sweetheart tree from Parkdale, OR in 2006 and maintained in $0.02 \%$ glycerol at $5^{\circ} \mathrm{C}$. Bacteria were harvested from a 2-day-old culture grown on Pseudomonas Agar F (PAF) (Difco Laboratories, Sparks, MD) by removing cells using a rubber spatula, suspended in sterile distilled water, and adjusted to 0.03 absorbance units at 600 $\mathrm{nm}$ as determined with a Nanodrop 1000 spectrophotometer (Thermo Scientific, Wilmington, DE) to obtain a suspension of $5.6 \pm 2.9 \times 10^{8} \mathrm{CFU} / \mathrm{ml}$. Concentration was confirmed by dilution plating on PAF.

Inoculation at injury-wound sites. Golden Heart and Sunset Bing trees were inoculated throughout the season to correspond with cultural operations and natural wounds that may be potential sites for infection. Wound types and month of inoculation are presented in Tables 1 and 2 . A heading cut was made on each newly planted tree by removing the terminal portion of the main trunk to leave a tree about $80 \mathrm{~cm}$ high. Each cut received 100 to 200 $\mu \mathrm{l}$ of inoculum. Scoring cuts were made in spring with two hacksaw blades taped together to produce a 1-mm-wide cut. Three limbs per tree were cut, and cuts were made $1 \mathrm{~cm}$ above the bud on three buds per limb. The circumference of the cut was just beyond the margins of the bud. Each cut was inoculated with $30 \mu$ of inoculum. Summer pruning cuts were made by removing about half of the current season's growth on two to six shoots per tree and applying 50 to $100 \mu \mathrm{l}$ per cut, depending on shoot diameter. At the beginning of natural leaf drop in autumn when leaves easily detached, leaves were removed and five leaf scars per shoot on three shoots per tree were inoculated with $10 \mu \mathrm{l}$ of inoculum per leaf scar. To simulate early-winter freezing injury, two shoots per tree were sprayed with three 1-s bursts of component cooler 64-4321 (RadioShack Corp., Ft. Worth, TX) designed to cool the sprayed surface to $-52^{\circ} \mathrm{C}$. Freeze-injured tissue was inoculated with 100 to $250 \mu \mathrm{l}$ per site with an atomizer. Component cooler also was used to simulate midwinter low-temperature injury. One to three shoots per tree were sprayed with four 1-s bursts of cooler, then inoculated after $30 \mathrm{~min}$ with $125 \mu \mathrm{l}$ of inoculum with an atomizer. Three dormant pruning cuts per tree were made in midwinter and inoculated with 0.1 to $1 \mathrm{ml}$ per cut for shoots ranging in diameter from 5 to 40 $\mathrm{mm}$, respectively. Adequate volumes were placed on all cut surfaces to completely cover the surface with inoculum. The inoculum was rapidly absorbed, and no runoff occurred. For each inoculation, there were 14 inoculated Sunset Bing and 8 inoculated Golden Heart trees and an equal number of control trees of each cultivar. Wounds on control trees were treated with sterile distilled water. Canker incidence and severity was assessed in June follow- ing each year's inoculation. Dead trees were counted in June 2009.

Cultivar-rootstock inoculation. Three strains of $P$. syringae pv. syringae (KM406, KM106, and KM 706) were isolated from different infected sweet cherry trees in a commercial orchard in Parkdale, OR in 2006 and maintained in $0.02 \%$ glycerol at $5^{\circ} \mathrm{C}$. Isolates were grown and prepared as described above. Each strain of $P$. syringae pv. syringae was adjusted to $1.8 \times 10^{8} \mathrm{CFU} / \mathrm{ml}$ and concentration was verified by dilution plating on PAF. Inoculum consisted of a combination of equal volumes of each $P$. syringae pv. syringae strain. After trees were planted in 2007, apices of young trees were removed to leave $80 \mathrm{~cm}$ of the tree above ground. From 100 to $200 \mu \mathrm{l}$ of inoculum was placed on the heading cut to provide adequate volume to completely cover the cut surface. In spring 2008 and 2009, two shoot terminals per tree were removed and cuts were inoculated with 50 to $100 \mu$ of inoculum, depending on shoot diameter. A single scoring cut per tree also was made on the trunk midway between the graft union and the first limb. The cut was made by starting on the north side of the trunk and cutting to the east side. Each scoring cut received $100 \mu \mathrm{l}$ of inoculum. At the beginning of natural leaf drop on 3 November 2008 when leaves easily detached, leaves were removed and five leaf scars per shoot on two shoots per tree were inoculated with $10 \mu \mathrm{l}$ of inoculum per leaf scar. Canker incidence (number of wounds

Table 1. Sites for infection on young sweet cherry trees cv. Sunset Bing ${ }^{2}$

\begin{tabular}{|c|c|c|c|c|c|c|c|c|c|c|c|c|c|c|c|}
\hline \multirow[b]{3}{*}{ Infection site } & \multirow[b]{3}{*}{ Month } & \multicolumn{6}{|c|}{ Wounds infected (\%) } & \multicolumn{6}{|c|}{ Canker length (mm) } & \multirow{2}{*}{\multicolumn{2}{|c|}{ Dead trees $(\%)$}} \\
\hline & & \multicolumn{2}{|c|}{ Year 1} & \multicolumn{2}{|c|}{ Year 2} & \multicolumn{2}{|c|}{ Year 3} & \multicolumn{2}{|c|}{ Year 1} & \multicolumn{2}{|c|}{ Year 2} & \multicolumn{2}{|c|}{ Year 3} & & \\
\hline & & Inoc & Cont & Inoc & Cont & Inoc & Cont & Inoc & Cont & Inoc & Cont & Inoc & Cont & Inoc & Cont \\
\hline Heading cut & May-June & $100 c^{*}$ & 93 & & & & $\ldots$ & $159 \mathrm{~b}^{*}$ & 35 & & & & & $86 \mathrm{~d}^{*}$ & 43 \\
\hline Scoring cut & March & $\ldots$ & $\ldots$ & $100 c^{*}$ & 5 & $100 \mathrm{~d}^{*}$ & 44 & $\ldots$ & $\ldots$ & $141 \mathrm{ab}^{*}$ & 2 & $191 \mathrm{e}^{*}$ & 22 & $21 \mathrm{ab}$ & 21 \\
\hline Summer pruning & August & $\ldots$ & $\ldots$ & $69 a^{*}$ & 55 & $81 \mathrm{c}$ & 97 & $\ldots$ & $\ldots$ & $227 a b^{*}$ & 39 & $70 \mathrm{c}$ & 13 & $64 \mathrm{c}$ & 29 \\
\hline Leaf scar & November & $39 \mathrm{a}^{*}$ & 0 & $95 b^{*}$ & 24 & $50 \mathrm{~b}^{*}$ & 0 & $16 \mathrm{a}^{*}$ & 0 & $272 \mathrm{~b}$ & 131 & $38 \mathrm{~b}^{*}$ & 0 & $71 \mathrm{c}^{*}$ & 21 \\
\hline Early-freezing injury & December & $63 b^{*}$ & 0 & $\ldots$ & $\ldots$ & $17 \mathrm{a}^{*}$ & 0 & $30 \mathrm{a}^{*}$ & 0 & - & $\ldots$ & $9 \mathrm{a}^{*}$ & 0 & $14 \mathrm{a}$ & 21 \\
\hline Low-temp. injury & January & $32 \mathrm{a}^{*}$ & 4 & $94 \mathrm{~b}^{*}$ & 58 & $23 \mathrm{a}^{*}$ & 0 & $18 \mathrm{a}^{*}$ & 2 & $249 b^{*}$ & 69 & $10 \mathrm{ab}^{*}$ & 0 & $64 \mathrm{c}$ & 43 \\
\hline Dormant pruning & February & $\ldots$ & $\ldots$ & $94 \mathrm{~b}^{*}$ & 26 & $97 d^{*}$ & 17 & $\ldots$ & $\ldots$ & $96 \mathrm{a}^{*}$ & 3 & $50 \mathrm{~d}^{*}$ & 0 & $29 \mathrm{~b}$ & 50 \\
\hline
\end{tabular}

${ }^{\mathrm{z}}$ Numbers followed by the same letter within columns are not significantly different at $P=0.05$ according to $\chi^{2}$ (wounds infected and dead trees) or analysis of variance general linear model and least significant difference (canker length); $*=$ inoculated (Inoc) significantly greater than control (Cont) at $P=0.05$ according to $\chi^{2}$ (wounds infected and dead trees) or $t$ test (canker length).

Table 2. Sites for infection on young sweet cherry trees cv. Golden Heart ${ }^{2}$

\begin{tabular}{|c|c|c|c|c|c|c|c|c|c|c|c|c|c|c|c|}
\hline \multirow[b]{3}{*}{ Infection site } & \multirow[b]{3}{*}{ Month } & \multicolumn{6}{|c|}{ Wounds infected (\%) } & \multicolumn{6}{|c|}{ Canker length (mm) } & \multirow{2}{*}{\multicolumn{2}{|c|}{ Dead trees $(\%)$}} \\
\hline & & \multicolumn{2}{|c|}{ Year 1} & \multicolumn{2}{|c|}{ Year 2} & \multicolumn{2}{|c|}{ Year 3} & \multicolumn{2}{|c|}{ Year 1} & \multicolumn{2}{|c|}{ Year 2} & \multicolumn{2}{|c|}{ Year 3} & & \\
\hline & & Inoc & Cont & Inoc & Cont & Inoc & Cont & Inoc & Cont & Inoc & Cont & Inoc & Cont & Inoc & Cont \\
\hline Heading cut & May-June & $100 \mathrm{c}$ & 100 & & $\ldots$ & & $\ldots$ & $146 \mathrm{~b}$ & 105 & & $\ldots$ & & & $75 d^{*}$ & 50 \\
\hline Scoring cut & March & $\ldots$ & $\ldots$ & $91 \mathrm{c}^{*}$ & 5 & $47 c^{*}$ & 0 & $\ldots$ & $\ldots$ & $59 \mathrm{bc} *$ & 1 & $40 b^{*}$ & 0 & $50 \mathrm{bc} *$ & 25 \\
\hline Summer pruning & August & & $\ldots$ & $50 \mathrm{~b}$ & 50 & $60 \mathrm{c}$ & 78 & & $\ldots$ & $20 a b$ & 4 & $14 \mathrm{bc}$ & 9 & $63 \mathrm{~cd}^{*}$ & 25 \\
\hline Leaf scar & November & $25 \mathrm{a}^{*}$ & 0 & $32 \mathrm{a}$ & 22 & $5 b^{*}$ & 0 & $18 \mathrm{a}^{*}$ & 0 & $4 \mathrm{a}$ & 9 & $1 \mathrm{a}$ & 0 & $25 \mathrm{a}$ & 37 \\
\hline Early-freezing injury & December & $17 \mathrm{a}$ & 10 & $\ldots$ & $\ldots$ & $8 b^{*}$ & 0 & $48 \mathrm{a}$ & 3 & $\ldots$ & $\ldots$ & $3 \mathrm{a}$ & 0 & $50 \mathrm{bc}$ & 37 \\
\hline Low-temp. injury & January & $64 b^{*}$ & 8 & $63 \mathrm{~b}$ & 81 & $0 \mathrm{a}$ & 0 & $44 \mathrm{a}^{*}$ & 5 & $32 \mathrm{ab}$ & 31 & $0 \mathrm{a}$ & 0 & $37 \mathrm{ab}$ & 37 \\
\hline Dormant pruning & February & $\ldots$ & $\ldots$ & $91 \mathrm{c}^{*}$ & 63 & $94 \mathrm{~d}^{*}$ & 38 & $\ldots$ & $\ldots$ & $96 \mathrm{c}$ & 47 & $23 \mathrm{c}^{*}$ & 1 & $25 \mathrm{a}^{*}$ & 13 \\
\hline
\end{tabular}

${ }^{2}$ Numbers followed by the same letter within columns are not significantly different at $P=0.05$ according to $\chi^{2}$ (wounds infected and dead trees) or analysis of variance general linear model and least significant difference (canker length); $*=$ inoculated (Inoc) significantly greater than control (Cont) at $P=0.05$ according to $\chi^{2}$ (wounds infected and dead trees) or $t$ test (canker length) 
infected) and severity (canker length in millimeters) were assessed in June following each year's inoculation. Dead trees were counted in June, 2009.

Transmission with pruning tools. Sweet cherry cv. Sunset Bing trees on Gisela 6 rootstock trees were planted in April 2007. In August 2007 and 2008 and January 2008 and 2009, a 15-cm length of main trunk about $2 \mathrm{~cm}$ in diameter on the trees was surface disinfested with $95 \%$ ethanol. A pruning tool (loppers) also was sterilized with $95 \%$ ethanol and used to cut through a bacterial canker that exhibited abundant gummosis and from which $P$. syringae pv. syringae was subsequently isolated in each trial. Within 1 min of cutting through the canker, the pruners were used to make successive heading cuts through the surface-sterilized trunk on three replicate trees. The process of sterilization, contamination, and cutting was done three times with different active cankers in each of the three trials. Controls consisted of making heading cuts on three replicate surface-sterilized trees with sterile pruners. For trees cut in January and August, lengths of cankers were measured after 4 to 5 and 11 to 12 months, respectively.

Duration of wound susceptibility. Sweet cherry cv. Sweetheart trees on Mazzard rootstock were planted in April 2007. Heading cuts were made in June and August 2007 and January 2008. At each time, cuts on three replicate trees were inoculated $0,1,2$, and 3 weeks after making the cut with $P$. syringae pv. syringae isolate KM406 adjusted to $5.6 \times 10^{8} \mathrm{CFU} / \mathrm{ml}$. Adequate volumes of inoculum (50 to 150 $\mu \mathrm{l})$ were used to completely cover the cut surface. Control trees were cut but not inoculated. Canker lengths of June and August cuts were measured 1 month after inoculation, and the January 2009 trial was evaluated 5 months after inoculation.

Statistical analyses. Canker severities (length in millimeters) for both injurywound site and cultivar-rootstock studies were transformed to $\log$ values (canker length +1 ), and treatment differences were determined with analysis of variance (ANOVA) for cultivar-rootstock values and the general linear model for injurywound site values. Means were separated with protected least significant difference at $P=0.05$. For each injury-wound site or cultivar-rootstock, the difference between the inoculated and control treatments was determined with a two-sample $t$ test. Differences in canker incidence (number of inoculations with infection) and in number of dead trees, as well as the difference between the inoculated and control treatments for each injury-wound site or cultivar-rootstock, were determined with $\chi^{2}$ tests at $P=0.05$. Data from experiments on transmission of $P$. syringae pv. syringae with pruning tools were analyzed with ANOVA. For duration of wound susceptibility, canker lengths were transformed to $\log$ values (length in $m m+1$ ) and analyzed with linear regression to determine the relationships between canker length and time from cutting to inoculation. All analyses were performed with statistical software (Minitab, State College, PA).

\section{RESULTS}

Inoculation at injury-wound sites. Infection occurred at all of the seven types of injury-wound sites on both Sunset Bing/Gisela 6 and Golden Heart/Mazzard trees (Tables 1 and 2). On Sunset Bing trees, infection of wounds made in spring and summer (scoring cuts in March, heading cuts when trees were planted in May, and summer pruning in August) resulted in the greatest canker incidence (number infected) and severity (canker length) (Table 1). Infection of wounds in winter (early-freezing injury in December, lowtemperature injury in January, and dormant pruning in February) resulted in the lowest canker incidence and severity. Inoculation of heading cuts resulted in the highest percentage of dead trees $(86 \%)$, followed by leaf scars $(71 \%)$, summer pruning $(64 \%)$, and low-temperature injury sites (64\%).

On Golden Heart trees, infection of heading cuts, scoring cuts, and dormant pruning cuts resulted in the greatest canker incidence of 69 to $100 \%$ and severity of 49 to $146 \mathrm{~mm}$ in canker length (Table 2). All other wound sites resulted in lower incidence of 13 to $55 \%$ and severity of 8 to 25 $\mathrm{mm}$ in length than heading, scoring, and dormant pruning cuts (Table 2). Heading cut inoculations resulted in the highest percent of dead trees (75\%) followed by summer pruning cuts $(63 \%)$.

Cultivar-rootstock inoculation. Although considerable variability occurred among wound sites and year, Bing and Sweetheart were overall the most susceptible cultivars while 'Regina' and 'Rainier' appeared to be more resistant. For example, Rainier had the smallest heading cut cankers, 'Sylvia' and Regina had the smallest scoring cut cankers, and Regina and Rainier had the smallest leaf scar cankers (Table 3). Shoots were more resistant than other wound sites with cankers less than $7 \mathrm{~mm}$ in length, and no differences occurred among cultivars. Bing trees had the highest mortality of any cultivar, with $70 \%$ dead at the end of the 3-year study. No cultivar by rootstock interactions were significant.

Among the three rootstocks, trees on Gisela 6 had the largest cankers at heading cuts and trees on Mazzard had the largest cankers at scoring cuts (Table 4). No rootstock differences were observed at leaf scar or shoot tip inoculation sites. In all, $77 \%$ of trees on Gisela 6 were dead at the end of the 3-year study. No rootstockcultivar interactions were significant.

Susceptibility of Bing on five different rootstocks varied with wound site and year. Heading cut cankers in Bing on Gisela 6 and Mazzard were larger than when Bing was on other rootstocks (Table 5). Scoring cut cankers were largest when Bing was on Mazzard or Colt rootstocks (Table 5). Cankers on vegetative shoots were largest when Bing was on Gisela 6 and Colt (Table 5). No differences among rootstocks were observed for leaf scar cankers. Bing on Gisela 6 had the highest incidence of dead trees $(90 \%)$, and Bing on Colt had the lowest incidence of dead trees $(0 \%)$.

Transmission with pruning tools. Canker incidence and size on trees cut with pruners that were used to cut through active bacterial cankers were not significantly different $(P=0.05)$ than on trees cut with sterile pruners. Mean canker lengths for trees cut with clean and contaminated pruners were 29 and $15 \mathrm{~mm}$, respectively, for January and 23 and $15 \mathrm{~mm}$, respectively, for August. In addition, there was no pattern when comparing the first, second, and third cuts in each series. Also, at the

Table 3. Bacterial canker severity on five sweet cherry cultivars at Hood River, OR ${ }^{\mathrm{x}}$

\begin{tabular}{lccccccc}
\hline & \multicolumn{5}{c}{ Canker length $(\mathbf{m m})$ for each infection site/year $^{\mathbf{y}}$} \\
\cline { 2 - 7 } Cultivar & Heading/2007 & Scoring/2008 & Scoring/2009 & Leaf/2008 & Shoot/2008 & Shoot/2009 $^{\text {Dead (\%) }} \mathbf{z}^{\mathbf{z}}$ \\
\hline Bing & $18.0 \mathrm{~b}$ & $13.6 \mathrm{bc}$ & $16.1 \mathrm{a}$ & $4.3 \mathrm{ab}$ & $5.2 \mathrm{a}$ & $2.6 \mathrm{a}$ & $70 \mathrm{~b}$ \\
Sweetheart & $12.6 \mathrm{a}$ & $13.8 \mathrm{bc}$ & $12.5 \mathrm{a}$ & $5.0 \mathrm{~b}$ & $6.6 \mathrm{a}$ & $4.3 \mathrm{a}$ & $43 \mathrm{a}$ \\
Sylvia & $12.1 \mathrm{a}$ & $8.2 \mathrm{a}$ & $10.8 \mathrm{a}$ & $2.7 \mathrm{ab}$ & $4.0 \mathrm{a}$ & $2.7 \mathrm{a}$ & $60 \mathrm{ab}$ \\
Regina & $11.3 \mathrm{a}$ & $10.6 \mathrm{ab}$ & $11.7 \mathrm{a}$ & $0.3 \mathrm{a}$ & $4.9 \mathrm{a}$ & $5.3 \mathrm{a}$ & $50 \mathrm{a}$ \\
Rainier & $9.5 \mathrm{a}$ & $15.7 \mathrm{c}$ & $11.0 \mathrm{a}$ & $0.5 \mathrm{a}$ & $4.4 \mathrm{a}$ & $3.5 \mathrm{a}$ & $47 \mathrm{a}$ \\
\hline
\end{tabular}

${ }^{x}$ Heading cuts in 2007, scoring and shoot cuts in 2008 and 2008, leaf scars in 2008, and percentage of trees dead in 2009. Data from Gisela 6, Mazzard, and

Maxma 14 rootstocks were combined for each cultivar.

${ }^{y}$ Numbers followed by the same letter within columns are not significantly different at $P=0.05$ according to analysis of variance and least significant difference tests.

${ }^{\mathrm{z}}$ Numbers followed by the same letter within columns are not significantly different at $P=0.05$ according to $\chi^{2}$ test. 
end of the study, $17 \%$ of trees cut with contaminated pruners and $17 \%$ of wounded control trees were dead.

Duration of wound susceptibility. All relationships between canker length and time from cutting to inoculation were significant, and susceptibility decreased as time increased (Table 6). In June or August, cankers that developed in cuts inoculated 1 to 3 weeks after wounding did not appear to be different in length from cankers in the noninoculated, wounded controls, which indicated that susceptibility of the wounds to infection during summer is less than 1 week. In January, cankers that developed in cuts inoculated 3 weeks after wounding did not appear different in length from cankers in the controls but cankers in cuts inoculated 1 and 2 weeks after wounding appeared of similar size to those inoculated immediately after wounding, indicating that wounds were susceptible for more than 2 weeks but less than 3 weeks.

\section{DISCUSSION}

Our results showed that $P$. syringae pv. syringae can cause infection of woody tissue of sweet cherry at any of several types of wound and injury sites on a tree. Severe infections and a high rate of tree mortality were related to heading cuts. These cuts are made on all sweet cherry trees shortly after planting in early spring. In the Pacific Northwest (PNW) of the United States, $P$. syringae pv. syringae populations on sweet cherry trees increase 10- to 100-fold during bloom in mid-April, the time many orchards are planted (16). In addition, $P$. syringae pv. syringae populations are higher in wetter climates such as the Mid-Columbia region of Oregon and Washington compared with drier areas farther east of the Cascade Mountains (16). Because bacteria often are disseminated by rain, heading cuts should be made during dry weather.

Although scoring and summer pruning cuts were potential sites for high incidence and severity of bacterial canker in our trials with a high inoculum dose, scoring usually is done before the spring increase of $P$. syringae pv. syringae populations, and summer pruning is done during dry, hot weather when $P$. syringae pv. syringae populations in the PNW are lowest (16). These horticultural operations have been done for many years in PNW commercial sweet cherry orchards and have not resulted in increased bacterial canker. Nevertheless, these wounds are potential sites for infection, and growers should not make these cuts if summer rain occurs or if overhead tree sprinklers are used for irrigation or evaporative cooling. Severe fire blight infection of apple, caused by the bacterium $\mathrm{Er}$ winia amylovora (Burrill 1882) Winslow et al., is associated with overhead tree sprinklers and is an example of a wetness-related orchard disease problem (28).

Table 6. Duration of susceptibility of heading cut wounds on sweet cherry cv. Sweetheart to infection by Pseudomonas syringae pv. syringae

\begin{tabular}{lccc}
\hline & \multicolumn{3}{c}{ Mean canker length $(\mathbf{m m})$ for each inoculation date } \\
\cline { 2 - 4 } Time (weeks) $)^{\mathbf{z}}$ & 6 June 2007 & 9 August 2007 & 30 January 2008 \\
\hline 0 & 25.0 & 11.5 & 9.7 \\
1 & 7.3 & 6.0 & 7.3 \\
2 & 6.0 & 4.0 & 5.7 \\
3 & 5.3 & 5.0 & 1.7 \\
Control & 3.7 & 3.7 & 1.3 \\
Regression $P$ & 0.046 & 0.038 & 0.010 \\
\hline
\end{tabular}

$\mathrm{z}$ Time between wounding and inoculation. June and August inoculations were evaluated after one mo, January inoculation after 5 mo. Control cuts were not inoculated. Regression: $\log (Y+1)=1.14$ $0.133 X$ for June, $\log (Y+1)=0.988-0.104 X$ for August, and $\log (Y+1)=1.07-0.224 X$ for January; where $Y=$ canker length (mm) and $X=$ time (weeks).

Table 4. Bacterial canker severity on three sweet cherry rootstocks at Hood River, $\mathrm{OR}^{\mathrm{x}}$

\begin{tabular}{lccccccc}
\hline & \multicolumn{7}{c}{ Canker length $(\mathbf{m m})$ for each infection site/year ${ }^{\mathbf{y}}$} \\
\cline { 2 - 6 } Rootstock & Heading/2007 & Scoring/2008 & Scoring/2009 & Leaf/2008 & Shoot/2008 & Shoot/2009 & Dead (\%) ${ }^{\mathbf{z}}$ \\
\hline Gisela 6 & $14.9 \mathrm{c}$ & $8.8 \mathrm{a}$ & $10.1 \mathrm{a}$ & $1.3 \mathrm{a}$ & $4.7 \mathrm{a}$ & $4.9 \mathrm{a}$ & $77 \mathrm{~b}$ \\
Mazzard & $12.2 \mathrm{~b}$ & $16.7 \mathrm{c}$ & $13.6 \mathrm{a}$ & $2.6 \mathrm{a}$ & $4.9 \mathrm{a}$ & $3.7 \mathrm{a}$ & $30 \mathrm{a}$ \\
Maxma 14 & $8.6 \mathrm{a}$ & $11.4 \mathrm{~b}$ & $10.9 \mathrm{a}$ & $2.4 \mathrm{a}$ & $5.9 \mathrm{a}$ & $3.9 \mathrm{a}$ & $45 \mathrm{a}$ \\
\hline
\end{tabular}

${ }^{x}$ Heading cuts in 2007, scoring and shoot cuts in 2008 and 2009, leaf scars in 2008, and percentage of trees dead in 2009. Data from all cultivars were combined for each rootstock.

${ }^{y}$ Numbers followed by the same letter within columns are not significantly different at $P=0.05$ according to analysis of variance and least significant difference tests.

${ }^{\mathrm{z}}$ Numbers followed by the same letter within columns are not significantly different at $P=0.05$ according to $\chi^{2}$ test.

Table 5. Bacterial canker severity on four sweet cherry rootstocks on cv. Bing at Hood River, OR ${ }^{\mathrm{x}}$

\begin{tabular}{lccccccc}
\hline & \multicolumn{7}{c}{ Canker length $(\mathbf{m m})$ for each infection site/year } \\
\cline { 2 - 6 } Rootstock & Heading/2007 & Scoring/2008 & Scoring/2009 & Leaf/2008 & Shoot/2008 & Shoot/2009 & Dead (\%) $)^{\mathbf{z}}$ \\
\hline Gisela 6 & $19.3 \mathrm{~b}$ & $8.4 \mathrm{a}$ & $11.0 \mathrm{ab}$ & $5.0 \mathrm{a}$ & $4.3 \mathrm{a}$ & $6.0 \mathrm{~b}$ & $90 \mathrm{c}$ \\
Mazzard & $16.7 \mathrm{~b}$ & $18.8 \mathrm{~b}$ & $16.6 \mathrm{~b}$ & $4.3 \mathrm{a}$ & $6.2 \mathrm{a}$ & $2.3 \mathrm{a}$ & $50 \mathrm{~b}$ \\
Colt & $7.3 \mathrm{a}$ & $17.1 \mathrm{~b}$ & $14.5 \mathrm{~b}$ & $4.4 \mathrm{a}$ & $7.6 \mathrm{~b}$ & $5.9 \mathrm{~b}$ & $0 \mathrm{a}$ \\
Krymsk 5 & $5.2 \mathrm{a}$ & $13.4 \mathrm{~b}$ & $12.0 \mathrm{a}$ & $3.4 \mathrm{a}$ & $4.0 \mathrm{a}$ & $3.3 \mathrm{a}$ & $43 \mathrm{~b}$ \\
\hline
\end{tabular}

${ }^{x}$ Heading cuts in 2007, scoring and shoot cuts in 2008 and 2009, leaf scars in 2008, and percent of trees dead in 2009.

${ }^{y}$ Numbers followed by the same letter within columns are not significantly different at $P=0.05$ according to analysis of variance and least significant difference tests.

${ }^{\mathrm{z}}$ Numbers followed by the same letter within columns are not significantly different at $P=0.05$ according to $\chi^{2}$ test. 
cherry has been reported previously $(14,29)$. Leaf scar infection of cherry is important in the United Kingdom but these infections are caused primarily by $P$. morsprunorum rather than $P$. syringae pv. syringae (13). In Oregon's Willamette Valley west of the Cascade Mountains, bud infections (dead bud) are common in sweet cherry (7). These infections originate at the base of outside bud scales between November and February but a small percentage take place through leaf scars.

Infection of noninoculated, wounded controls was high at several wound siteyear combinations and was attributed to the high overall incidence of bacterial canker in the two experimental orchards. Gummosis was associated with many but not all cankers and is a common source of bacterial cells for dissemination by rain and insects (23).

Resistant cultivars and rootstocks play a critical role in management of bacterial canker. We included five widely planted cultivars in this study and found that, although resistance varied with infection site and year, cvs. Rainier and Regina appeared more resistant than Sweetheart and Bing. Bing accounts for more sweet cherry acreage in the PNW than any other cultivar $(32,33)$. Previous reports also consider Bing and Sweetheart to be susceptible to bacterial canker $(1,3,9)$.

Rootstock significantly affected cultivar susceptibility to bacterial canker. Mortality of $P$. syringae pv. syringae-inoculated trees on Mazzard was $30 \%$ but increased to $77 \%$ when trees were on Gisela 6 rootstock. Although no Bing on Colt rootstock died when inoculated with $P$. syringae pv. syringae, mortality of Bing on Gisela 6 was $90 \%$. Garrett (15) reported that Colt was more resistant to bacterial canker than the Prunus avium F12/1 clonal rootstock, a widely planted rootstock with some resistance to canker (6). The Gisela 6 rootstock has potential resistance based on leaf and twig bioassays $(2,20)$ but trees on Gisela rootstocks showed increased susceptibility in field observations (31).

We were unable to transmit bacterial canker in summer or winter by cutting through active cankers, then immediately using the same pruning tool to make heading cuts on healthy trees. Although Pseudomonas syringae pv. syringae was isolated from the tissue of all cankers, we did not determine whether or not $P$. syringae pv. syringae was on the pruning tool. In total, 30 transmission attempts were made in our study but additional research with a larger sample size is needed. The reason for lack of transmission is not known. Contaminated pruning tools can be an important means of spreading the fire blight bacterium from blighted to healthy pear branches $(4,30)$.

We found that heading cuts become resistant to infection after about 1 week in summer and 3 weeks in winter. Wounds on pear shoots became resistant to $P$. syringae pv. syringae infection after 3 days in spring and summer (26). Perennial canker of stone fruits caused by Leucostoma cincta (Fr.) Höhn and L. persoonii (Nitschke) Höhn invades the host through wounds. Wound healing is temperature dependent, requiring approximately 390 accumulated degree days $\left(0^{\circ} \mathrm{C}\right.$ base $)$ for complete healing (5). Sweet cherry growers should be encouraged to prune during dry weather and apply protective measures if rain occurs before cut tissues become resistant to infection.

An integrated approach is necessary for successful management of bacterial canker of sweet cherry (11). Because all natural and man-made injuries and wounds are susceptible to infection by $P$. syringae $\mathrm{pv}$. syringae, injuries should be avoided whenever possible. Infection sites also should be protected until healing occurs. Bacterial canker is reduced when tree trunks are painted white to reduce winter injury (27). Growers are encouraged to make heading, pruning, and scoring cuts only during dry weather. Heading cuts and leaf scars are particularly susceptible and require additional protection but copper-based products often provide poor control of bacterial canker (10), and effective products are still under development. None of the cultivarrootstock combinations consistently showed high resistance to bacterial canker but Bing on Gisela 6, which had a mortality of $90 \%$, should not be planted in areas where bacterial canker is a problem. Resistance to bacterial canker must be a high priority in future sweet cherry breeding programs.

\section{ACKNOWLEDGMENTS}

We thank A. Chozinski for technical help, Van Well Nursery and Willow Drive Nursery for donation of trees, and Columbia Gorge Fruit Growers for partial funding of research.

\section{LITERATURE CITED}

1. Allen, W. R., and Dirks, V. A. 1978. Bacterial canker of sweet cherry in the Niagra Peninsula of Ontario: Pseudomonas species involved and cultivar susceptibilities. Can. J. Plant Sci. 58:363-369.

2. Azarenko, A. N., and McCluskey, R. 1998. Performance of 'Napoleon' trees topworked on selected Giessen, MxM, GM, Colt, and Mazzard rootstocks. Acta Hortic. 468:321-326.

3. Bedford, K. E., Sholberg, P. L., and Kappel, F. 2003. Use of a detached leaf bioassay for screening sweet cherry cultivars for bacterial canker resistance. Acta Hortic. 622:365368.

4. Beers, S. V., and Rundle, J. R. 1987. Disinfectants for treating pruning shears used for fire blight infections. Acta Hortic. 217:243.

5. Biggs, A. R. 1995. Leucostoma canker. Pages 28-30 in: Compendium of Stone Fruit Diseases. J. M. Ogawa, E. I. Zehr, G. W. Bird, D. F. Ritchie, K. Uriu, and J. K. Uyemoto, eds. American Phytopathological Society Press, St. Paul, MN.

6. Cameron, H. R. 1962. Diseases of deciduous fruit trees incited by Pseudomonas syringae van Hall. Oreg. State Univ. Agric. Exp. Stn. Tech. Bull. 66.

7. Cameron, H. R. 1962. Mode of infection of sweet cherry by Pseudomonas syringae. Phytopathology 52:917-921.

8. Cameron, H. R. 1970. Pseudomonas content of cherry trees. Phytopathology 60:1343-1346.

9. Cameron, H. R. 1971. Effect of root or trunk stock on susceptibility of orchard trees to Pseudomonas syringae. Plant Dis. Rep. 55:421-423.

10. Carroll, J. E., Robinson, T. L., and Burr, T. J. 2007. Contributions of copper sprays, pruning stubs, training system and cultivar towards management of Pseudomonas-incited cankers on sweet cherry. (Abstr.). Phytopathology 97:S18.

11. Castagnoli, S., Riedl, H., Spotts, R. A., Long, L. E., Shearer, P., Pscheidt, J. W., and Olsen, J. 2009. Pest Management Guide for Tree Fruits in the Mid-Columbia Area. Oreg. State Univ. EM 8203-E.

12. Cockayne, A. H. 1915. Dying of young fruit trees. N. Z. J. Agric. 11:504-506.

13. Crosse, J. E. 1956. Bacterial canker of stone fruits. II. Leaf scar infection of cherry. J. Hortic. Sci. 31:212-224.

14. Dye, D. W. 1954. Blast of stone-fruit in New Zealand. N. Z. J. Sci. Technol. 35:451-461.

15. Garrett, C. M. E. 1986. Influence of rootstock on the susceptibility of sweet cherry scions to bacterial canker, caused by Pseudomonas syringae pvs. morsprunorum and syringae. Plant Pathol. 35:114-119.

16. Gross, D. C., Cody, Y. S., Proebsting, E. L., Jr., Radamaker, G. K., and Spotts, R. A. 1983. Distribution, populations dynamics, and characteristics of ice nucleation-active bacteria in deciduous fruit tree orchards. Appl. Environ. Microbiol. 46:1370-1379.

17. Gross, D. C., Cody, Y. S., Proebsting, E. L., Jr., Radamaker, G. K., and Spotts, R. A. 1984 Ecotypes and pathogenicity of ice-nucleationactive Pseudomonas syringae isolated from deciduous fruit tree orchards. Phytopathology 74:241-248.

18. Grubb, N. H. 1936. Bacteriosis of cherry trees: relative susceptibility of varieties at East Malling. J. Pomol. Hortic. Sci. 15:25-34

19. Hattingh, M. J., and Roos, I. M. M. 1995. Bacterial canker. Page 48-50 in: Compendium of Stone Fruit Diseases. J. M. Ogawa, E. I. Zehr, G. W. Bird, D. F. Richie, K. Urio, and J. K. Uyemoto, eds. American Phytopathological Society Press, St. Paul, MN.

20. Roche, M. M. 2001. Development of an in vitro and modification of an in vivo bioassay to screen cherry genotypes for response to inoculation with Pseudomonas syringae pv. syringae. MS thesis, Oregon State University, Corvallis.

21. Roche, M., and Azarenko, A. N. 2005. An in vitro bioassay to evaluate sweet cherry response to inoculation with Pseudomonas syringae pv. syringae. Acta Hortic. 667:503 508.

22. Santi, F., Russell, K. Menard, M., and Dufour, J. 2004. Screening wild cherry (Prunus avium) for resistance to bacterial canker by laboratory and field tests. For. Pathol. 34:349-362.

23. Schumann, G. L., and D'Arcy, C. L. 2006. Essential Plant Pathology. American Phytopathological Society, St. Paul, MN.

24. Sobiczewski, P., and Jones, A. L. 1992. Effect of exposure to freezing temperatures on necrosis in sweet cherry shoots inoculated with Pseudomonas syringae pv. syringae or $P$. s. morsprunorum Plant Dis. 76:447-451.

25. Spotts, R. A., and Cervantes, L. A. 1994. Pseudomonas canker of pear trees in Oregon, cultivar resistance, and effect of trunk guards on canker incidence and bacterial survival on bark. Plant Dis. 78:907-910

26. Spotts, R. A., and Cervantes, L. A. 1995. Factors affecting the severity of bacterial canker of pear caused by Pseudomonas syringae pv. syringae. Plant Pathol. 44:325-331

27. Spotts, R. A., Facteau, T. J., Cervantes, L. A., and 
Chestnut, N. E. 1990. Incidence and control of cytospora canker and bacterial canker in a young sweet cherry orchard in Oregon. Plant Dis. 74:577-580.

28. Spotts, R. A., Stang, E. J., and Ferree, D. C. 1976. Effect of over-tree misting for bloom delay on incidence of fireblight in apple. Plant Dis. Rep. 60:329-330.

29. Sundin, G. W., Jones, A. L., and Olson, B. D.
1988. Overwintering and population dynamics of Pseudomonas syringae pv. syringae and P.s. pv. morsprunorum on sweet and sour cherry trees. Can. J. Plant Pathol. 10:281-288.

30. Teviotdale, B. L., Wiley, M. F., and Harper, D. H. 1991. How disinfectants compare in preventing transmission of fire blight. Calif. Agric. JulyAug.:21-23

31. Thornton, G., and Nugent, J. 2002. Bacterial canker suppression. www.maes.msu.edu/nwmi hort.

32. USDA. 2006. Oregon fruit tree inventory. In: National Agricultural Statistics Service. http:// Www.nass.usda.gov/or.

33. USDA, 2006. Washinton fruit survey. National Agricultural Statistics Service. http://www. nass.usda.gov/Statistics_by_State/Washington/ Publications/Fruit/FruitTreeInventory2006.pdf. 